UDC 027.7:[37:376]

BILOUS V. S.

Library, Vinnytsia Mykhailo Kotsiubynskyi State Pedagogical University (Vinnytsia, Ukraine), e-mail: vspu.lib@gmail.com, ORCID 0000-0003-2998-400X

BROVCHAK L. S.

Vinnytsia Mykhailo Kotsiubynskyi State Pedagogical University (Vinnytsia, Ukraine), e-mail: info@vspu.edu.ua, ORCID 0000-0001-8321-9267

\title{
THE ROLE OF THE LIBRARY IN THE FORMATION OF INCLUSIVE COMPETENCE OF FUTURE TEACHERS: RELEVANCE, DIRECTIONS, EXPERIENCE
}

\begin{abstract}
Objective. The article is aimed at reviewing the current state of inclusion implementation in Ukraine and the role of university libraries in these processes. Methods. The research was conducted by analyzing the world literature on educational practices of development and implementation of inclusion and experience of the library of Vinnytsia Mykhailo Kotsiubynskyi State Pedagogical University (VSPU) in creating inclusive library space. Results. The term "inclusive education" is explained and the factual basis of the importance of training highly qualified teachers in the conditions of inclusive education is expanded. The essence of inclusive teacher competence as a scientific category is analyzed. Emphasis is placed on the experience of the VSPU library in creating an inclusive library space. It is proved that the library, using various forms and methods of work, promotes the introduction of the latest educational standards, among which is the inclusive education. The main directions and aspects of the implementation of the inclusive project "Library without Borders" are highlighted. Conclusions. Ukrainian educational institutions take an active part in inclusive education practices. In these processes, the university library is an important link in providing inclusive education. The necessity of supplementing the further strategy of the library activity with the direction of formation of inclusive space and inclusive library is determined.

Keywords: inclusive education; inclusive competence; inclusive environment; inclusive library; people with special needs; Vinnytsia Pedagogical University Library
\end{abstract}

\section{Introduction}

Realization of rights and opportunities for everyone, creation of "society for all" provides equal access to knowledge and opens a wide aspect for the development of every citizen of the country, protection and integration of all segments of the population, including people with special needs into society, provides for the creation of a comfortable inclusive space. The problem of inclusive education and the organization of inclusive space is a topic of discussion in Ukraine at the state, scientific and practical levels. At the present stage of society development, Ukraine is in the process of changing the educational space, focused on Western European standards. After ratification of the Convention on the Rights of Persons with Disabilities, the standards of ensuring the right to education of children (people) with disabilities have become mandatory for Ukraine (Instytut spetsialnoi pedahohiky NAPN Ukrainy, 2017). Inclusive education is a system of educational services that ensures the realization of the right to education of persons with special educational needs, as well as their socialization and integration into society. The system of inclusive education is aimed at implementing the principles of democracy, humanism, justice, individual approach to all participants in the educational process, especially to children with special educational needs (Holiuk \& Smoliak, 2018).

Ukraine joined the educational space of inclusive education in 2012. However, domestic scientists began to study and focus on this process much earlier. Among them are V. Bondar, 
V. Bocharov, B. Vulfov, I. Demchenko, A. Kapska, A. Kolupaieva, V. Lypa, V. Synov, S. Kharchenko, M. Chaikovskyi and others.

In the scientific field, research is actively conducted on various aspects of working with children with special educational needs, theoretical and practical forums are held, scientific and methodological literature is published, etc. (Demchenko, 2016). The problem of inclusive education is the object of research by specialists in the field of psychology, social, inclusive and correctional pedagogy (O. Akimova, V. Andrushchenko, O. Holiuk, O. Demchenko, A. Kolupaieva, K. Krutii, A. Korol, I. Lapshyna, Z. Leniv, V. Liakhov, L. Savchuk, T. Sak, O. Taranenko, A. Khil and others). Considering the concept of "inclusive educational environment", researchers interpret it as a set of conditions, factors and infrastructure objects that ensure the acquisition of sociality for persons with special social needs through their inclusion in all parts of the pedagogical process, free residence in the educational institution, an important component of which there is also a library.

\section{Literature analysis.}

Millions of children with moderate or severe disabilities around the world do not have access to quality education. The solution to this problem are the systems of inclusive education: preschools, schools, social services. Inclusion issues are relevant and are being explored around the world. Scientists conduct field research using a variety of methods: interviews, discussions, semi-structured interviews with teachers and students. The results of these studies require critical reflection on inclusive education policy and help improve educational opportunities for children around the world. The results of these studies require critical reflection on inclusive education policy and help improve educational opportunities for children around the world. Inclusive education is a "revolutionary" educational concept that aims to promote the participation of all students in the learning process (Opoku, Nketsia, Fianyi, \& Laryea, 2020).

Scholars around the world are considering legislative improvements to inclusive education to increase the likelihood of children with disabilities attending school. There is a Teachers Agency for Inclusive Education. This pedagogical agency promotes inclusive education and carries out agential actions of teachers regarding inclusive education: learning strategies, cooperation, familyschool-community ties and other active actions (Miller, Wilt, \& Allcock, 2020).

Particular attention is paid to higher education institutions where students with special needs study and which train specialists to work in the field of inclusion. These questions are the result of field research that studies teacher training and pedagogical practice in the process of including students with disabilities in higher education. The methodological approach is qualitative, and the research has a descriptive-research nature, such as Case Study. The analysis revealed that the lack of knowledge of teachers about the concept of educational inclusion is caused by their formative path and that this applies to inclusive pedagogical practice. Research shows that experience of scientists could raise new perspectives on the personal and social potential of students with disabilities (Santos Costa, Soares Modica, \& Nascimento dos Santos, 2020).

Today, more than ever, there is a need to provide inclusive education for students with disabilities. Therefore, the need for universities to develop and implement educational policy on inclusion is considered (Morina, Perera, \& Carballo, 2020; Demchenko, 2016).

Thus, teachers from seven different Spanish universities, who were recommended by their students with disabilities, based on best practices, took part in a research that resulted in three key elements to improve the academic experience of students with disabilities: special training for teachers concerning disabilities, good relations between teachers and students and the willingness to make reasonable adjustments. Teachers should develop flexible teaching with positive and tolerant attitudes towards their students, in order to improve the quality of the academic and social experience for students with disabilities (Aguirre, Carballo, \& Lopez-Gavira 2020). 
Foreign scholars emphasize the importance of promoting the development and systematization of high-quality research and documentation collections on the best practices of inclusive education in schools (Covelli \& Lucia, 2020) and the coverage of their achievements in scientometric databases.

The issue of inclusion, formation of inclusive library is also a new and extremely important direction of activity of a modern educational institution library. It requires modernization of the library, the availability of the necessary equipment and facilities, providing appropriate information resources to users (Bilous, 2018). For example, the Ukrainian researcher T. Kolesnykova (2019), based on a detailed analysis of world practices, emphasizes the need to include libraries of Ukrainian universities together with teachers in the practice of creating open digital textbooks (Open Textbook). Because it is the projects for the creation and availability of free open textbooks that expand the educational prospects for people with disabilities.

A necessary factor in the work of the library with users with special needs is a psychological factor - the sense of empathy that they expect from a library employee. Indeed, this is considered one of the key skills of helping this category. Thus, according to the study by researchers at the University of Malaysia (Bodaghi, Cheong, \& Zainab, 2016) data collected through interviews and focus group discussions with visually impaired students who were registered in the university library were used. People with special needs seek to feel a sense of belonging to an educational institution, to an academic library. They are sensitive to the greetings and friendly conversation of librarians, their voice tone, their sense of understanding of their limitations, and have a gust of changes in the library environment as key factors illustrating their empathy and attitude toward them. In addition, such people are usually afraid to ask for help; they are frustrated, confused, embarrassed, and misunderstood because of the librarians' lack of empathy.

At the same time, the issue of inclusion, the formation of inclusive library is a big gap in the library activities of both foreign and domestic libraries, which take an active part in providing information to various categories of readers, including people with special needs.

That is why the purpose of our article is to review the current state of inclusion in Ukraine and the role of university libraries in these processes.

\section{Methods}

The research was conducted by analyzing the world literature on educational practices of development and implementation of inclusion and experience of the library of Vinnytsia Mykhailo Kotsiubynskyi State Pedagogical University (VSPU) in creating inclusive library space.

\section{Results and Discussion}

Vinnytsia Mykhailo Kotsiubynskyi State Pedagogical University pays great attention to the issue of inclusion, training of qualified specialists who are able to effectively perform their professional duties in an inclusive environment. Today in VSPU in general, at the faculty of preschool, elementary education and arts in particular, research work in the field of inclusive pedagogy and training specialists for work in the inclusive educational space of preschool and general secondary education was initiated. One of the key problems in the implementation of inclusion is the qualified training of future teachers. It is well known that its efficiency largely depends on the process of formation of methodological, theoretical, practical and psychological readiness of students for teaching in inclusive environment (Demchenko, 2016). 
In our opinion, in creating a modern educational environment in pedagogical educational institutions, which would provide the necessary conditions, means and technologies for the successful training of future teachers who will work with children with special educational needs, the library should be given a proper place. Currently, the issue of inclusion is an important area of activity of the VSPU library, which is reflected in the implementation of the inclusive project "Library without Borders" and involves the creation of inclusive library, formation of inclusive space. The educational library, using various forms and methods of library work, acts as a leader of humanistic ideals, popularizer of the best examples of world pedagogical thought, introduces the latest educational standards, among which is inclusive education. The library participates in the formation of inclusive competence of teachers, carries out extensive informational and librarybibliographic work on the preparation of future teachers who will use their knowledge of inclusive education in further pedagogical activities.

In close cooperation with the university departments and the department of youth policy and social work, the library plays a significant role in the formation of future teachers, in the formation of inclusive competence, promotes training of future professionals, which is very important and priority at the current stage of reforming the education system. The implementation of this task requires a comprehensive approach and involves radical changes in the organization of the library work, establishing close cooperation of librarians with the university administration and other professionals (teachers, psychologists, physicians, social workers).

A high level of competence implies the possession of professional knowledge, skills and abilities, as well as the ability to navigate in difficult situations and make optimal decisions, a sufficient level of necessary professional and personal qualities. It is worth noting that librarians in terms of inclusion, in addition to their usual activities, pay special attention to the category of users with special needs; they are able to choose the necessary materials, as well as they are able to predict possible difficulties. It is the librarian, his/her professional readiness and skill that determines not only the quality of the information resource and the efficiency of providing information, but also how comfortable users will feel in an inclusive environment.

The main condition for creating a modern educational and information environment of the library is the reform of the physical spatial and subject environment, the formation of information resources and active implementation of the latest information and communication technologies. This process is characterized by general requirements, among which are those that ensure its inclusive context:

- library work planning and design of information and educational space of the library should be aimed at personal development and motivation to learn and actively use library services (compliance of educational and library environment with the requirements of ergonomics, widespread use of new IT technologies, multimedia tools, library renewal, etc.);

development of infrastructure to provide various forms of library service (creation of educational online platform with educational and methodological materials for different categories of users, which will help to provide library services remotely);

- implementation of ideas of inclusive education (creation of conditions for learning to use the library and its resources for users with special needs; introduction of individual development programs, including correctional and rehabilitation measures, psychological and pedagogical support and necessary teaching aids).

Given the above, the library has identified two main priority directions of work concerning the inclusive education.

1 -st direction. Improving the service of people with special educational needs and creating comfortable conditions for them to meet information needs. 
This includes, firstly, the creation of a barrier-free environment for educational institutions and libraries, and in particular, the arrangement of the surrounding area for comfortable movement of people with disabilities, installation of ramps, equipment of stairs with special markings and coverings, appropriate width of doorways and corridors, no thresholds and floor height differences, tactile signs, special equipment for toilet facilities, etc. Secondly, the availability of inclusive resource zones and their arrangement in accordance with the special needs of library users: quiet interior, special architectural solutions, mobile comfortable furniture, multifunctionality of the room (zoning), computer and multimedia equipment, special teaching materials, computer programs and means of information perception, adapted to the needs of students with various disabilities, etc.

In accordance with current regulations (Pro osvitu, 2017), the VSPU pays due attention to ensuring the rights of persons with disabilities and other low-mobility groups in all areas of the educational process and their full inclusion in society, as well as creating unimpeded access for people with disabilities at the level of other persons. University premises are available and have a universal design. Measures are constantly being taken to create and improve a barrier-free space for all categories of people with disabilities: those with musculoskeletal, vision, hearing disorders and other mobility impaired groups: the elderly, pregnant women, parents with children and others. Vinnytsia Pedagogical University has arranged:

- $\quad$ elevators, ramps, special lifts and other means of accessibility for people with musculoskeletal disorders;

- $\quad$ the university website uses various visual elements: created pages "Virtual Tour" and "Distance Education"; the library's website contains a sound "Business Card" and audio shelf for the visually impaired people.

- duplication of important sound information by texts, use of reinforcement system for people with hearing impairments (use of headphones).

The VSPU library uses methods and forms of library activity to participate in measures to create adequate social protection and support, social integration, create equal opportunities for selfrealization, full life, education and employment, involvement of people with disabilities in spiritual and cultural life. The library has a universal space available to every user. Due attention is paid to people with special needs. Conditions have been created for comfortable accommodation in the library, for minimal time and effort to meet the reading needs of visitors. Today, the library is accessible to people with disabilities and people with limited mobility. The entrance to the building is equipped with a ramp and handrails. The central entrance of the library is located at the floor level of the indoor premises; the front door allows unobstructed access to the library. The internal space of the library allows safe movement of people in wheelchairs, the front door allows one to easily get to the electronic information room and electronic reading room.

2-st direction. Support and assistance in the educational process at the university concerning the introduction of inclusive education by developing a number of forms and methods of information and library work to help future teachers.

The organization of inclusive environment in the library involves not only the adaptation of the premises and the workplace to service and provide information to users with special needs, but also educational and methodological support, individual approach to each, advice, which is the basis for student interest in learning. A feature of the modern library as an institution of socialization of young people with disabilities is the integration of this category of users into the community life, which is realized through educational, leisure, creative, informational and volunteer activities (Bilous, 2020).

The library takes an active part in conferences, meetings, seminars, forums on inclusion (The International Congress on the basis of Vinnytsia Pedagogical University on special pedagogy, 
psychology and rehabilitation "Education of children with special needs: from institutionalization to inclusion," celebration of the World Down Syndrome Day, book-illustrative exhibitions: "Sunny children", "We are all equal, we are all different." Together with the Vinnytsia. Down. Syndrome Social Organization we took part in the design of the photo exhibition "We are different, but we are among you!" and in the charity event).

Based on the need to improve the service of people with special educational needs and create appropriate conditions for them to meet their information needs, we developed and implemented a number of transformations for quality service and the creation of a kind of inclusive library (Bilous, 2020). Servicing users with special needs provides remote access to library resources. Library staff are developing a web-based distance learning environment. Significant assistance in promoting inclusive education is provided by the library's website, which presents materials for people with special needs: a business card of the site, virtual audio shelf of works of art, links to useful sites. The library plans to have audio versions of individual pages of the site.

To meet the needs of the modern user, providing prompt access to all library and information resources, the library masters and actively implements modern achievements in the field of information, communication and multimedia technologies in library processes. As part of their core responsibilities, librarians provide free Internet access, obtaining information by e-mail, information and consulting support, search of educational and information sites, advice on the use of PCs and electronic resources (Bilous, 2010). The use of information and communication technologies is a significant factor in the education efficiency of students with special needs, the introduction of inclusion in the library space and positive changes in the formation of inclusive competence. They open wide opportunities for improving the quality of education, its accessibility. In addition, the introduction of ICT helps to make library services more efficient, high quality and interesting.

The library carries out extensive informational and library-bibliographic work on the preparation of future teachers who will use their knowledge of inclusive education in further pedagogical activities. The library has a significant array of literature on inclusion, which is becoming the subject of increased attention. The paper and electronic resources of the library to support inclusive education are presented by scientific and popular publications. The collection includes books published in the framework of the project "Inclusive education for children with special needs in Ukraine." The library promotes the education at student youth of the best human and civic qualities, expanding intellectual abilities, informs about information resources to help the education and upbringing of children with special needs. The content of educational work includes the development of inclusive education, the formation of students' humanistic worldview, humane attitude to man, society, the formation of tolerance, charity and Christian morality. Among the most common types of cultural and educational work of the library, which consider the inclusion issues, we note the following: book exhibitions, virtual exhibitions, informational and informationalthematic reviews, thematic, thematically commented and informational reviews, conversations, meetings, presentations, Department Days, Information Days, etc. The library has organized book exhibitions: "Inclusive education and school management", "Inclusive education", "Fundamentals of inclusive education" (Bilous, 2018). The library provides "privileged" access to information resources, if desired - the opportunity to use the "night delivery room." It also provides consultations for working with computers and the Internet, promotes the inclusion in the life of the university and library, takes care of organizing interesting cultural and educational activities, conducts master classes in the club "Creative handcraft". 


\section{Conclusions}

Ukrainian educational institutions are actively involved in inclusive education practices. The university library is an important link in these processes. The library creates an inclusive space, an inclusive library, both for those who study and need special conditions, and promotes the formation of inclusive competence of future teachers, and for future professionals in inclusive education. In order to improve the service of people with special needs, to create information products and services, as well as to learn about the best practices in inclusion, for example, the VSPU library develops appropriate measures, outlines a strategy in this area and identifies key forms of work.

We understand that the reorientation to new forms of work will increase the library prestige as a social institution that can help young people with disabilities to integrate into the learning environment, future teachers to acquire knowledge of inclusive education and implement acquired knowledge in practice. That is why our strategy is to create an inclusive library, the main criteria of which are: the availability of the library, its resources and services; innovative methods of service and provision of adapted resources for users with special needs; implementation of informational and educational activities through participation in conferences, seminars, round tables, trainings, master classes on the organization of inclusive education; interaction with university departments, libraries, public associations, etc.

\section{REFERENCES}

Aguirre, A., Carballo, R., \& Lopez-Gavira, R, (2020). Improving the academic experience of students with disabilities in higher education: faculty members of Social Sciences and Law speak out. Innovationthe European journal of social science research, October, 175-188. doi: https://doi.org/10.1080/13511610.2020.1828047 (in English)

Bilous, V. S. (2010). Formuvannia ta vykorystannia elektronnykh resursiv u bibliotetsi Vinnytskoho derzhavnoho pedahohichnoho universytetu imeni Mykhaila Kotsiubynskoho. Naukovi pratsi Derzhavnoi naukovo-pedahohichnoi biblioteky Ukrainy imeni V. O. Sukhomlynskoho, 2, 210-215. Retrieved from http://journals.dnpb.gov.ua/article/viewFile/75423/74312 (in English)

Bilous, V. S. (2018). Inkliuzyvne seredovyshche biblioteky: stratehiia rozvytku. Inkliuzyvna osvita yak indyvidualna traiektoriia osobystisnoho zrostannia dytyny z osoblyvymy osvitnimy potrebamyiu: zbirnyk materialiv II Vseukrainskoi naukovo-praktychnoi konferentsii, 08-09 lystopada 2018, Vinnytsia, $\quad 1, \quad 31-34 . \quad$ Retrieved from http://library.vspu.net/bitstream/handle/123456789/3851/Zbirnik_inkluzija_2018.pdf?sequence=1 \&isAllowed $=y$ (in Ukrainian)

Bilous, V. S. (2020). Osvitianska knyhozbirnia - terytoriia inkliuzyvnoho prostoru. Bibliotechnyi forum: istoriia, teoriia $i$ praktyka, 1, 17-20. Retrieved from http://library.vspu.net/handle/123456789/4781?show=full (in Ukrainian)

Bodaghi, N. B., Cheong, L. S., \& Zainab, A. N. (2016). Librarians Empathy: Visually Impaired Students' Experiences Towards Inclusion and Sense of Belonging in an Academic Library. Journal of academic librarianship, 42(1), 87-96. doi: https://doi.org/10.1016/j.acalib.2015.11.003 (in English)

Covelli, A., \& Lucia, de A., (2020). The quality of inclusive education in Italy: The view of teachers in training for inclusive education of pupils with special educational needs. Alter-European journal of disability research, 14(3), 175-188. doi: https://doi.org/10.1016/j.alter.2020.04.002 (in English) 
Holiuk, O., \& Smoliak, I. (2018). Formuvannia inkliuzyvnoi kompetentnosti maibutnikh pedahohiv. Inkliuzyvna osvita yak indyvidualna traiektoriia osobystisnoho zrostannia dytyny z osoblyvymy osvitnimy potrebamyiu: zbirnyk materialiv II Vseukrainskoi naukovo-praktychnoi konferentsii, 0809 lystopada 2018, Vinnytsia, 1, 42-46. Retrieved from http://library.vspu.net/bitstream/handle/123456789/3851/Zbirnik_inkluzija_2018.pdf?sequence=1 \&isAllowed $=\mathrm{y}$ (in Ukrainian)

Demchenko, I. I. (2016). Teoretychni i metodychni zasady pidhotovky maibutnoho vchytelia pochatkovykh klasiv do profesiinoi diialnosti $\mathrm{v}$ umovakh inkliuzyvnoi osvity. (Avtoreferat dysertatsii doktora pedahohichnykh nauk). Umanskyi derzhavnyi pedahohichnyi universytet imeni Pavla Tychyny, Uman. Retrieved from https://dspace.udpu.edu.ua/handle/6789/7977 (in Ukrainian)

Instytut spetsialnoi pedahohiky NAPN Ukrainy. (2017). Normatyvnyi biuleten: dovidnyk. Kyiv; Chernivtsi: Bukrek. (in Ukrainian)

Kolesnykova, T. (2019). The Role of Libraries as Publishers in the Open Education Landscape: Reflecting Modern World Practice of Open Textbooks. University Library at a new stage of social communications development. Conference proceedings, 4, 88-99. doi: http://dx.doi.org/10.15802/unilib/2019_187423 (in English)

Miller, A. L., Wilt, C. L., \& Allcock, H. C. (2020). Teacher agency for inclusive education: an international scoping review. International journal of inclusive education, July, doi: https://doi.org/10.1080/13603116.2020.1789766 (in English)

Morina, A., Perera, H. P., \& Carballo, R. (2020). Training Needs of Academics on Inclusive Education and Disability. Sage open, September, 1-10. doi: https://doi.org/10.1177/2158244020962758 (in English)

Opoku, M.1 P., Nketsia, W., Fianyi, I., \& Laryea, P. (2020). Inclusive education for students with sensory disabilities in Ghana: views of students with disabilities about availability of resources in regular schools. Disability and rehabilitation-assistive technology, August. doi: https://doi.org/10.1080/17483107.2020.1807623 (in English)

Pro osvitu: Zakon Ukrainy. № 2145-VIII. (2017). Retrieved from https://zakon.rada.gov.ua/laws/show/2145-19\#Text (in Ukrainian)

Santos Costa, P. L., Soares Modica, N. D., \& Nascimento dos Santos, C. L. (2020). Teaching training and pedagogical practice in the process of inclusion of young students with disabilities in higher education institutions. Revista Práxis Educacional, 16(42), 115-134. doi: https://doi.org/10.22481/praxisedu.v16i42.7339 (in English)

БІЛОУС В. С.

Бібліотека, Вінницький державний педагогічний університет імені Михайла

Коцюбинського (Вінниця, Україна), e-mail: vspu.lib@gmail.com,

ORCID 0000-0003-2998-400X

БРОВЧАК Л. С.

Вінницький державний педагогічний університет імені Михайла Коцюбинського, (Вінниця, Україна), e-mail: info@vspu.edu.ua, ORCID 0000-0001-8321-9267

\section{РОЛЬ БІБЛІОТЕКИ У ФОРМУВАННІ ІНКЛЮЗИВНӦ̈ КОМПЕТЕНТНОСТІ МАЙБУТНІХ ПЕДАГОГІВ: АКТУАЛЬНІСТЬ, НАПРЯМИ, ДОСВІД}

Мета. Стаття спрямована на здійснення огляду актуального стану впровадження інклюзії в Україні та ролі університетських бібліотек в цих процесах. Методика. Дослідження проводилось шляхом аналізу світової 


\section{CHANGING ROLES: FROM INFORMATION PROVIDERS TO EDUCATORS}

літератури щодо освітніх практик розроблення й впровадження інклюзії та досвіду роботи бібліотеки Вінницького державного педагогічного університету імені Михайла Коцюбинського (ВДПУ) в створенні інклюзивного бібліотечного простору. Результати. Пояснено термін «інклюзивна освіта» та розширено фактологічну базу важливості підготовки висококваліфікованих педагогів в умовах інклюзивної освіти. Проаналізовано сутність інклюзивної компетентності вчителя як наукової категорії. Акцентовано увагу на досвіді роботи бібліотеки ВДПУ щодо створення інклюзивного бібліотечного простору. Доведено, що бібліотека, використовуючи різноманітні форми і методи роботи, сприяє впровадженню новітніх освітніх стандартів, серед яких - інклюзивна освіта.Виділені основні напрями та аспекти впровадження інклюзивного проєкту «Бібліотека без меж». Висновки. Українські заклади освіти активно долучаються до практик інклюзивної освіти. В цих процесах університетська бібліотека $є$ важливою ланкою в забезпеченні інклюзивного навчання. Визначено необхідність доповнення подальшої стратегії діяльності бібліотеки напрямком щодо формування інклюзивного простору та інклюзивної бібліотеки.

Ключові слова: інклюзивна освіта; інклюзивна компетентність; інклюзивне середовище; інклюзивна бібліотека; люди з особливими потребами; бібліотека Вінницького педуніверситету 